\title{
Lymphomatous Adult T-Cell Leukemia/Lymphoma
}

National Cancer Institute

\section{Source}

National Cancer Institute. Lymphomatous Adult T-Cell Leukemia/Lymphoma. NCI

Thesaurus. Code C36266.

An adult T-cell leukemia/lymphoma characterized by generalized lymphadenopathy without peripheral blood involvement. Most patients have advanced disease, however hypercalcemia is not frequently present. -- 2004 